\title{
Evaluation of Erosion Effects on Some Roads in Yenagoa City of Bayelsa State, Nigeria
}

\author{
Nkemjika C C ${ }^{1}$, Akobi C. C ${ }^{2}$, Onuoha K. C $C^{3}$ Idhoko K.E ${ }^{4}$ \\ Department of Surveying and Geoinformatics, Nnamdi Azikiwe University Awka, Anambra State, Nigeria
}

\begin{abstract}
This research evaluates the effects of erosion some roads in Yenagoa city of Bayelsa State. Reconnaissance survey was carried out to assist in the identification and accurate delimitation of the study area. Factors responsible for erosion in the study area were observed to ranges from natural cause including topography, rainfall and soil nature. Human factor responsible for erosion in the area studied include land use pattern and waste disposal method, poor construction and maintenance activity. Effect of erosion on the studied area includes Rendering of road way non motor able through creation of gullies, Carving in (slope instability) on drains ditches that were not lined, Flooding of road ways during rain due to blockage of drains, Pollution of water bodies in the environment as a result of sediment deposition, Destruction of Pavement infrastructure i.e. pavement, culverts and drainages. It is therefore concludes that Erosion also have various effects on street roads not all factors assumed to be responsible for erosion form agricultural perspective is responsible for erosion on street roads. However, with good management practices, and paving of roads, the problems of erosion in built up area can be controlled. This research focussed on the production of street roads map that guide the assessment and evaluation of impact of erosion in some part of Yenagoa metropolis Bayelsa state. Digital surveying method was adopted through the use already existing map of the city and field data obtain from GPS survey. Some features were coordinated using GPS for updating the new features that does not exist on the old map. Important features such as roads, etc were obtained from the existing map. Ground truthing and field editing were also carried out. All the processing was carried out using AutoCAD 2010 and ArcGIS software.
\end{abstract}

Keywords: Reconnaissance Survey, Erosion, Runoff, Street Roads, and Road infrastructure

\section{Introduction}

Roads are very vital to the transportation of people and goods, and to promote development (Oyedepo and Oluwajana, 2013, Robinson and Thagesen, 2004); however, (Oyedepo and Oluwajana, 2013) opined that the menace of erosion on road has made some of it not to fulfill the purpose for which it was built. Also, according (Oyedepo and Oluwajana, 2013, Auzet, 2005) Runoff and soil erosion are among the major environmental threats around the world, they occur under very diverse conditions depending on interactions between land use, climate, soils and topography.

(Oyedepo and Oluwajana, 2013, Smith et al, 2003) stated that water erosion is the removal of soil from earth's surface by running water (Schwab et al, 1992). It is the straight forward wearing away by the mechanical abrasion caused by suspended particle (Lister and Cook, 2006.). Soil water erosion is a major environment issue (Franco et al 2010), it can be a consequence of degradation of the soil structure, especially the functional attributes of soil pores to transmit and retain water, and to facilitate root growth (Lujan 2003). Runoff occurs only when the rate of precipitation exceeds the rate at which water infiltrates into the soil (Musa et al, 2010). However, Runoff and soil loss prediction has been widely used as a tool to guide conservation planning (Lujan, 2003). Erosion creates dangerous conditions on pathways and roadways; it can undercut and cause bank failure on pedestrian and vehicle routes, increasing risk of injury and death (Pineo and Barton 2009). When rain falls onto the earth surface, it moves according to the law of gravity, a portion of the precipitation seeps into the ground to replenish earth's ground water, but most of it flows downhill as runoff (Musa et al 2010). Runoff is extremely important. It not only does serve rivers and streams, but also changes the landscape by an action of erosion (Musa et al,
2010).Flowing water has tremendous power, it can move boulders and carve out canyons (Aneke 1985). Water erosion needs to be controlled to maintain motor-able roads, crop productivity, and sedimentation and stream pollution. Erosion problems are principally caused by human exploitation of natural resources and the removal of the protective cover of natural vegetation (Schwab et al 1992).Erosion has been a menace in our society. It has been a problem in agricultural and engineering sector. It has been a problem affecting both highways and streets road with the problem of erosion on highways mostly reported and investigated. Erosion on streets road that provides accessibility to populace into their home has been a menace under discussed. However the incessant problem of gully on road, carving in on bridges and swelling of pavement foundation due to ingress of uncontrolled water and runoff into the pavement foundation, and crater thereby compounding road failure necessitated the need to investigate the causes, effect and ways of proffering solution to the problem of erosion on road ways. Hence, this research evaluates the impact of erosion and runoff on street road

\subsection{Description of the Study Area}

The project area starts from Opolo- Epie junction on Mbiama/ Yenagoa road on the right side of the Epie Creek to the Isaac Boro express behind and terminates at sliver bird link road to Swali market road junction. It lies within the coordinates of $0062014.7 \mathrm{E}, 045623.7 \mathrm{~N}, 0062010.3 \mathrm{E}, 04$ $5658.6 \mathrm{~N}, 061533.7 \mathrm{E}, 045525.0 \mathrm{~N}$ and $0061652.0 \mathrm{E}, 04$ $5424.5 \mathrm{~N}$ respectively. Its cut across Epie and Atisa clan were the creek haven (Government house) resides 


\section{International Journal of Science and Research (IJSR) ISSN (Online): 2319-7064}

Index Copernicus Value (2013): 6.14 | Impact Factor (2014): 5.611

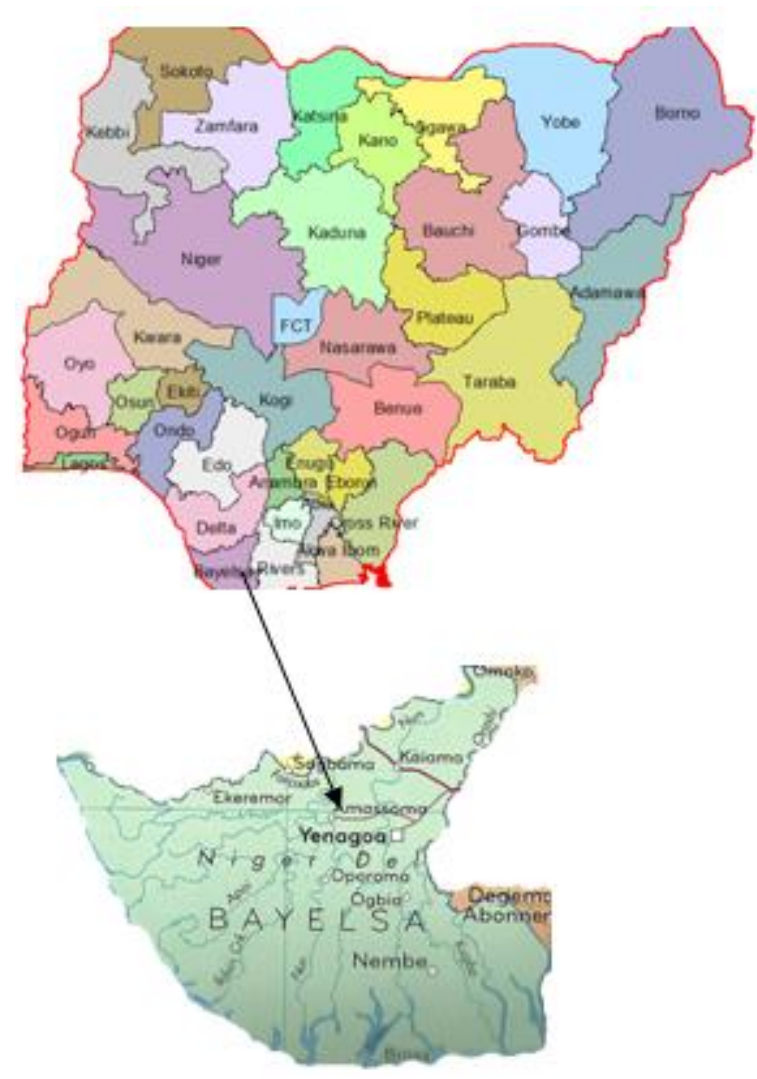

Figure 1: Map of Bayelsa State

\subsection{Statement of Problem}

The availability of bad roads in different parts of Bayelsa State and especially Yenagoa Urban area cannot be over emphasized; these are occasioned by both manmade and natural causes. Yenagoa Urban is a swampy area and road construction should be done in such a way that it will withstand the test of time but this is not the case with some roads this makes some portion of the road to give away easily .The non availability of good drainage channels and inability to de-silt filled up drainage channels contribute to the failed portions other reasons include application of chemical substances on the road. Without maintenance these roads become death traps and causes traffic congestion. When rehabilitating an existing road it is useful to assess the quality and effectiveness of the existing drainage system. The reason for the failure of a road section can often show signs of its shortcomings through excessive scouring, accumulation of silt or entire washouts.

Before carrying out drainage improvements, it is important that the reasons for the damages are fully understood. When surveying the works, try to establish the exact cause and effect of the drainage failures. On this basis, more effective improvements can be made to the road drainage and hopefully reduce future maintenance demands, and increase the lifetime of the road.

Obviously, the design of proper drainage relies on careful studies at site. Equally important, the drainage patterns and requirements should be observed during rainy periods, in order to obtain a realistic impression of the how, and how much, water is moving in the vicinity of the road.

\section{Methodology}

Primary and secondary sources of data were used for this research. Two main sources of primary data were employed, namely, household survey and measurement of pedestrian walkways. Also, field observations were equally adopted to check the functionality of drainage system as well as the condition of road surface on the sampled routes in the study area. The household survey was carried out using structured questionnaire to solicit information on the households' perception on the provision, utilization and maintenance culture of transport infrastructure connecting their residential units. In yenagoa, where the research was conducted, three roads each were randomly selected from Trunk A-Federal Roads (highways), Trunk B-State Roads, and Trunk CLocal Government Roads to assess the maintenance of the urban transport corridors in the city. This implies that information was collected on nine roads selected from all areas of the city. In each of the sampled road, a systematic random sampling technique was employed to select an average of fifteen buildings each along the selected road segments on the principle of one in every $20^{\text {th }}$ building. In each of the residential building sampled, only one head of household is selected and interviewed. Once the initial household has been selected for questionnaire administration, others follow in sequential order. Descriptive statistics such as tables of percentages was used to analyze the data.

\subsection{Reconnaissance Survey of the Study Area}

Reconnaissance survey of the study area which is from Opolo- Epie junction on Mbiama/ Yenagoa road on the right side of the Epie Creek to the Isaac Boro express behind and terminates at sliver bird link road to Swali market road junction was carried out to assist in the identification and accurate delimitation of the study area. Essentially, the survey was done in order to collect proper information on the extent and nature of erosion occurrence on street roads. Also, residents were interviewed to ascertain the direct effect of soil erosion and management practices in the area. Figure 1 shows the Street Map of the study area. Extent of erosion damage in the case study area was examined through visual inspection. Street taken into consideration for this study are opolo-Epie,Akali street and yenizue-gene etc. During the reconnaissance survey, the following features were examined namely Road type (paved or unpaved), Road infrastructures such as drain, culverts etc., Terrain (Flat or sloppy), Land use management. Pictures of the most affected areas were taken for thorough examination and the causes and the effect of erosion on the areas were then studied.

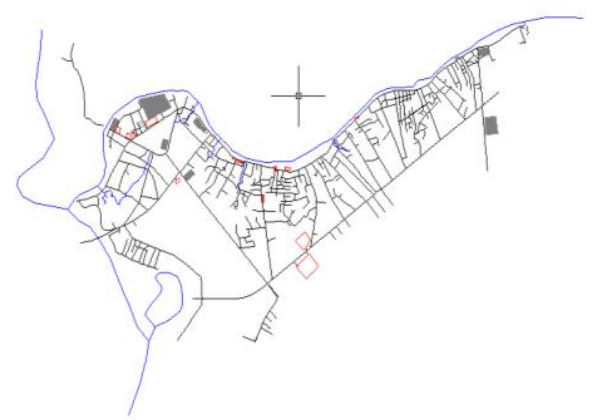

Figure 2: Reconnaissance diagram showing the project area 


\section{International Journal of Science and Research (IJSR) \\ ISSN (Online): 2319-7064}

Index Copernicus Value (2013): 6.14 | Impact Factor (2014): 5.611

\section{Results and Discussion}

Erosion impact in the selected study area was found to vary from Minor to Severe and the main causes of erosion in these areas is water, these usually occur during the raining season. The level of impact of erosion on the street considered was determined by the ability of the streets to provide access to resident. Inability of the street to provide access to vehicle and residents were judge "severe", partial accessibility termed "Major", and relative low erosion impact termed "Minor ". Unpaved roads are familiar sight on streets. Almost all of these roads are used for daily transportation by residents except for those in a total state of disrepair. Erosion is perhaps the most challenging problem is all the area considered for study. However management of unpaved street roads in these areas has not received attention as much as paved roads. Furthermore an integrated catchment drainage system was not present in all the study cases.

\subsection{Evaluation of Factors Responsible for Erosion on Case Study Streets}

Erosion which is a fundamental and complex natural process was observed to be strongly affected by human activities. The cause of erosion in these areas was view from natural perspectives and human perspectives.

\subsection{Natural Causes of Erosion}

Various factors were observed to be responsible for erosion problem on the case study streets. These factors include topography of the terrain, land use pattern, soil nature, rainfall, and poor maintenance practice of road infrastructure as well as absence of proper drainage. However the factor that controls the impact of erosion on unpaved roads differs from that of paved roads.

\subsubsection{Rainfall}

An important factor that controls the level of the impact of erosion on road is rainfall. It is an important factor that must be considered in assessing erosion. Without rainfall erosion cannot occur in the selected area.

\subsubsection{Topography}

Topography was observed to be one of the critical factors affecting erosion in the study area especially on agilobi, Epie, Street. The topography of the area mentioned was observed to be sloppy and hence whenever rain fall movement of water is favoured toward the lower elevation which in turn discharged runoff with it impeding sediments into an adjacent stream that is not lined. This consequently causes the stream to over flow it banks unleashing flood to buildings that lies along its banks. Similar sloppy terrain was observed on all other site.On New Agudama street, Eke street, , which is tarred (i.e.paved) the effect of topography on ability of the road to be eroded was insignificant. However it contributed to storage of runoff into craters which aid in the development of pothole on these roads. A situation where topography contributed to ability of runoff to erode the paved layer off the road consequently affecting the subgrade soil. In some cases at, Johnson, akenfa and old agudama street, the topography of the terrain has contributed to washing off of the soil that served as foundation for the drainages and culverts leaving them to fail during subsequent erosion.

\subsubsection{Soil Condition}

To an extent when rainfall water infiltrates into the existing soils that serve as the foundation for these unpaved street roads and when water input exceed the soil's capacity to absorb water runoff occur. Runoff when improperly channeled lead to erosion. On most of the unpaved roads studied there exist underlying impervious rock layers leading to formation of gully when the loose soil particles that overly these road has been remove.

Such a scenario was observed on Akenfa street.

Particularly, Erosion impact was found to be severe on igbogene street. Also, terrain where underlying impervious layers does not exist, craters were created making such road non motor able. A typical example of such was found at akenpai Street.

On some street road selected as case study there exist a loose sandy gravel soil, so when rain falls they are easily washed off. Soil condition was observed not to be a factor influencing erosion on paved roads

\subsubsection{Land Use Pattern and Waste Disposal Method}

Land use pattern in the areas studied were observed to be terrible. Some of the buildings were observed to be constructed on waterway. Also the way refuses were dumped in the existing drainage limited the way in which drainage performs and when drainages which are expectedto be conveying runoff from the road surfaces are obstructed it causes erosion. This often aids in the development of gully on roadway and sometimes flooding which affect both homes and pavement infrastructures

\subsubsection{Poor Maintenance Practices}

Poor maintenance practices of exiting drainages in one of the important factor that was observed to leads to erosion. Drainage system is known for carrying surface runoff and loosens soil particles. When these particles are carried by runoff, they settle out in the drainage or where there is obstruction in the drainage system thus diminishing the carrying capacities of the ditches. However in the studied area, poor maintenance of existing drainage infrastructure (i.e. Drains and Culverts) causes obstruction in the flow of runoff which in turn causes roadway flooding. Typical example of this can be found on New agudama Street. In this case, uncontrolled run off and incessant disposal of wastes into the drainage channel often causes flooding when rainfall and this has also lead to carving in of the cross culvert that provide access to other parts of the streets.

\subsubsection{Poor Construction Activity}

Another factor that causes erosion on roadway including paved and unpaved road is poor construction activity. Road drainages are constructed without taken anticipated runoff into consideration and this often leads to the design of drains that cannot hold and channel runoff into the nearby stream. Similarly, culvert inlets are designed improperly. Also improper construction of drainages and culvert were also found to cause road erosion. Drain that was supposed to be 


\section{International Journal of Science and Research (IJSR) \\ ISSN (Online): 2319-7064}

Index Copernicus Value (2013): 6.14 | Impact Factor (2014): 5.611

constructed using concrete retaining wall at one side and block wall on the other were observed to be constructed using double block wall. Alternate drying and shrinkage of these block wall by rain lead to dying shrinkage and whenever these occur they tend to give way to erosion thereby causing runoff to flow on road surfaces. Typical example can be seen on Plate 7 , in this case a double block wall.

\subsection{Effect of Erosion on the Study Case Environment}

Effects of erosion on various case studied streets were observed to vary from severe to minor affecting homes streets and water bodies. However the following were observed to be the effects of erosion in environment of the study case area;

1) Rendering of road way is not motor able through creation of gullies

2) Carving in (slope instability) on drains ditches that were not lined

3) Flooding of road ways during rain due to blockage of drains

4) Pollution of water bodies in the environment as a result of sediment deposition

5) Destruction of Pavement infrastructure i.e. pavement, culverts and drainages

\section{Conclusion}

The effect of surface runoff and erosion on street roads in agilobi and its environs cannot be overemphasized as most residence find their roads non useable and their homes non accessible. Drivers encounter problems on the roads during the peak rainy season because of the increased number of potholes on the road created by surface runoff, road flooding and caving in of culverts and gullies. Therefore based on the survey carried out, it can be concluded that;

- Erosion also have various effects on street roads Not all factors assumed to be responsible for erosion form agricultural perspective is responsible for erosion on street roads

- The causes of erosion on street roads ranges from natural factors such as topography of the terrain, soil nature, rainfall and human factors such as land use, poor waste disposal methods, poor construction and maintenance activity

\subsection{Recommendations}

Based on the study carried out, it can be recommended that;

- Maintenance of proper road crown for good drainage.

- Ensuring that ditches are properly lined to prevent erosion. Regular maintenance to keep ditches, drains and culverts clear

- Inspection of culverts on regular basis.

- Protecting inlets and outlet of culverts through the use of rip rap

- Installing diversions at all drain and culverts where runoff velocity can cause erosion

\section{References}

[1] ANEKE, D.O. (1985): "The Effects of Changes in Catchment Characteristics on Soil Erosion in Developing Countries (Nigeria)". Agricultural Engineer 40: 131-5.

[2] AUZET A.V.(2005): "From Soil Erosion Knowledge to Soil Protection and Runoff Prevention" COST 623. Soil Conservation and Protection for Europe

[3] FRANCO A.M.P., CASSOL E.A., PAULETTO E.A AND PINTO L. F.S(2010): "Flow hydraulic Characteristics and Interrill Erosion Susceptibility of Natural and Constructed Soils from Candiota Coal Mining Area, RS, Brazil".19th World Congress of Soil Science, Soil Solutions for a Changing World, 1 - 6 August 2010, Brisbane, Australia.

[4] LISTER D.H AND COOK W.G. (2006): "Erosion Corrosion". Erosion for Engineers

[5] LUJAN D.L. (2003): "Soil Physical Properties Affecting Soil Erosion in Tropical Soils." Facultad de Agronomia, Instituto de Edafologia, Universidad Central de Venezuela, Maracay, Venezuela.

[6] MUSA J.J, ABDULWAHEED S., AND SAIDU M.,(2010): "Effect of Surface Runoff on Nigerian Rural Roads (A Case Study of Offa Local Government Area)".AU J.T. 13(4): 242-248

[7] OGUNBODEDE, E.F. (2006): “Application of GIS to the Management of Traffic Congestions in Akure, Ondo state, Nigeria." PGD Project submitted to RECTAS, Obafemi Awolowo University, Ile-Ife, Nigeria

[8] OWOLABI, A.O. (2009): "Para-transit Modal Choice in Akure Nigeria: Application of Behavioural models". Institute of Transportation Engineers Journal, Vol. 79(1), $54-58$

[9] OYEDEPO O.J AND OLUWAJANA S.D. (2013) "Impact of Erosion on Street Roads: A Case Study Of Sijuwade Area Akure Ondo State Nigeria" Chemistry and Materials Research,ISSN 2224- 3224 (Print) ISSN 2225- 0956 (Online) Vol.3 No.10, 2013

[10] PINEO R. AND BARTON S.,(2009): "Preventing Erosion" Sustainable Landscapes Series .College of Agric and Natural Resources. University of Delaware.

[11] ROBINSON R. AND THAGESEN B. (2004): "Road Engineering for Development". Spoon Press, London

[12] SCHWAB, G.O.; FANGEMEIER, D.D.; ELLIOT, W.J.; AND FREVERT, R.K. (1992): "Soil and Water conservation Engineering ". John Wiley \& Sons, New York, NY, USA.

[13] SMITH C.J, FIELD J.B, JAKEMAN A.JAND LETCHER R.A. (2003 ): "Targeting Gully Erosion at a Catchment Scale". 